\title{
Crowdfunding and Crowdmicrofinance, an Evolution of Models for Entrepreneurship of the Poor
}

\author{
Laurence Attuel-Mendes \\ Univ. Bourgogne Franche-Comté, Burgundy School of Business-CEREN, Dijon, France \\ Email: Laurence.attuel-mendes@bsb-education.com
}

How to cite this paper: Attuel-Mendes, L. (2016) Crowdfunding and Crowdmicrofinance, an Evolution of Models for Entrepreneurship of the Poor. Open Access Library Journal, 3: e3251.

http://dx.doi.org/10.4236/oalib.1103251

Received: November 21, 2016

Accepted: December 10, 2016

Published: December 13, 2016

Copyright () 2016 by author and Open Access Library Inc.

This work is licensed under the Creative

Commons Attribution International

License (CC BY 4.0).

http://creativecommons.org/licenses/by/4.0/

(c) (i) Open Access

\begin{abstract}
After the boom of microfinance, we witness boom of crowdfunding. Thus, it is interesting to study their interactions. Benefiting both of a rich historic heritage, these two notions, even though non-synonymous, aim at similar goals. Funding of the economy for the latter poverty alleviation and financial eradication for the former-in its welfarist definition-make it quite logical that these two notions meet to serve each other. Indeed, they stand to be a major lever for entrepreneurs, for whom fundraising has always been an issue. Microfinance has become a tool of democratisation of entrepreneurship funding, while crowdfunding potentially opens entrepreneurship funding to masses. Combining both crowdfunding and microfinance can lead to an acceleration of poverty eradication.
\end{abstract}

\section{Subject Areas}

Business Finance and Investment, Entrepreneurship

\section{Keywords}

Microfinance, Crowdfunding, Entrepreneurship, Fundraising, Poverty Eradication

\section{Introduction}

After the boom of microfinance, we witness boom of crowdfunding. Thus, it is interesting to study their interactions. Benefiting both of a rich historic heritage [1] [2], these two notions, even though non-synonymous, aim at similar goals. Funding of the economy for the latter poverty alleviation and financial eradication for the former-in its welfarist definition [3] - is quite logical that these two notions meet to serve each 
other. Indeed, they stand to be a major lever for entrepreneurs, for whom fundraising has always been an issue.

Microfinance, thanks to Pr. Yunus's theorization, Nobel Peace Prize along with Grameen Bank, has become an essential funding tool for entrepreneurship of the poor, mainly feminine. It contributed to improve live conditions of millions of people. Crowdfunding is neither only targeted to entrepreneurship nor to the specific target of women or poor. Nevertheless, it permits a potential opening to masses of entrepreneurship funding in general, and towards poor in particular.

In order to measure their common perspectives, we need to explain quickly these two keywords of the 21st century economics. This will permit to assess in which extent crowdfunding is about to allow an acceleration in reaching the microfinance goal, meaning poverty eradication, by using its modern tools.

\section{Microfinance, Tool of Democratisation of Entrepreneurship Funding}

First, the field of microfinance needs to be explored in terms of population concerned by poverty and access to finance.

The number of people in the world living with less than $\$ 1.25$ per day decreases from 1.9 to 1 billion between 1981 and 2001 [4] while the rate of those living with less than $\$ 1.25$ per day was divided by three: $16.7 \%$ of developing countries inhabitants live with less than $\$ 1.25$ per day against 52.8\% 30 years ago. People living with less than $\$ 2$ per day are 2.1 billion, e.g. roughly one third of the global population, against $70 \%$ in 1981 . These figures are encouraging but difficulties remain. In developing countries, entrepreneurship is sometimes the only way to survive and to try to get out of poverty [5] [6] [7]. Through entrepreneurial engagement, it is expected to create its own wealth and to be emancipated from poverty rather than wait for charity. But access to credit-primary determining factor behind the success of ventures according to millions of poor profitable micro-entrepreneurs-through formal channels is quite impossible. Those populations don't meet banks' risk requirements such as collateral. The microfinance institutions (MFIs) with their unconventional group-lending models began to emerge as a potential player to fill the financing gap for microenterprises. They grant credits of small sum of money with high interest rates because of huge financial intermediation costs and lack of collateral. The initial model based on group-lending [8] demonstrate that poor are able to reimburse their debts if credits are adapted [9]. In this system, the group members use their social capital to jointly assume liability and peer-monitor their loans, thereby mitigating the information asymmetric risks for the lender [10] [11]. Nevertheless, this is not perfect, notably because of increase of intermediation costs, which led to rise of interest rates and a reimbursement crisis. These headed to an evolution of the methodology toward an individual and flexible product, resembling more traditional bank loans [12].

The success of this model saw the rise of a growing microfinance market for micro-entrepreneurial financing across the world. The market has stabilized [13] with an 
average growth rate of $30 \%$ per annum worldwide [14] in 2009. However, the growth rates were far higher than this mean value in the developing world markets than the developed world. Today, we still observe a double-digit growth but only reach $12.9 \%$ in portfolio and 10.3\% in number of borrowers between 2012 and 2013 [15] for 105.9 million of clients. The growth potential per annum until 2019 is assessed at $19.3 \%$ [16].

Another concept can be used by entrepreneurs to fund their activity.

\section{Crowdfunding, Potential Opening to Masses of Entrepreneurship Funding}

Second, new tools of financing must be explored to access more easily to financing.

Crowdfunding has been defined under different terms, from different points of view, academic [17] [18] or professional [19]. In simple terms, crowdfunding relies on the meeting of non-professional investors and entrepreneurs via internet platforms. $41.3 \%$ of crowdfunding, or $\$ 6.7$ billion, deal with business and entrepreneurship, against $18.9 \%$, or $\$ 3.06$ billion, for social causes [20].

Different types of crowdfunding coexist: beside classical charity, where no return is expected except from a personal moral satisfaction, we can find the hope for a reward (item or service), debt with the reimbursement of a loan with or without interest, and equity with receiving a stake in a company.

Donation-based crowdfunding is not really connected to the microfinance issue since it relies on charity and not credit. On the contrary, the other types can. Around 30 platforms are dedicated to microfinance in the world, even if this figure is in constant evolution as well as the sector itself. Lots of platforms are created each year while many others disappear. There is around 1250 crowdfunding platforms in 2015 in the world. The most famous in microfinance are Kiva in the USA, Rang De, in India, and Babyloan in France.

Lending platforms work as an intermediary between microfinance institutions (MFIs) and lenders. This is mostly crowd-to-business platforms as opposed to real peer-to-peer lending. Money is given by the investor through the platform to the MFI who has already given the loan to the poor entrepreneur. These platforms are strict in selecting MFIs for several reasons, mainly repayment issues and social impact. Investor is repaid for its investment over a period of time with or without interest and sometimes with fees. MyC4 uses a system of inverted auction to set the interest rate charged by the lender. Kiva doesn't charge any interest neither for the investor nor the MFI, which is consistent with its objective of casting aside poverty by targeting entrepreneurs around the globe. Babylaon, who replicates Kiva's model with minor differences, propose free interest loans for investors but does charge interests to MFIs.

Equity-based crowdfunding is the most complex and highly regulated form of crowdfunding [21]. Investors receive a stake in the company and share the profits and risks. This type is not widespread in the microfinance sector. Two main models of equity-based crowdfunding exist: the investors can become a stakeholder individually or through a holding, which would be stakeholder itself of the funded venture. A system of royalties exists as well. 
The figures of crowdfunding are tremendous, with a collect beyond $\$ 16.2$ billion in 2014 worldwide (up to $\$ 34.4$ billion in 2015) with a growth of $167 \%$ in one year [20]. North America still accounts for the largest market. According to [22], crowdfunding is likely to create 60 million new angels investors in the US alone thanks to JOBS Act.

Several factors can explain this growing enthusiasm for crowdfunding [23]: evolution of the classical scheme of exclusive funding by banks, growing competition of public and private actors, bashing of banks after the global crisis, reinforcement of prudential constraints of Basel III, development of alternative movements, such as slow movement and short circuits, development of new technologies of information and communication, political and regulatory support with the implementation of specific frameworks in some countries such as the USA.

These figures raise new hope for microfinance [24].

\section{Crowdfunding as a Vehicle for Crowdmicrofinance, towards an Acceleration of Poverty Eradication}

We can observe an historical proximity between crowdfunding and microfinance through the ancestors of microfinance, namely ROSCAs, for rotating savings and credit associations, and credit cooperatives. Their common trait is that the money lent comes from the crowd. Nevertheless, the main difference is that the crowd and the borrower necessarily know each other in the archaic mode. This is not the case for crowdfunding if the first circle of investors, family and friends, is overrun.

Some MFIs already tried to use the crowdfunding vehicle in order to develop their activity and fulfil their mission. Oikocredit was strongly connected to crowdfunding through MicroPlace platform since the launch of this platform by eBay in 2007 [25]. Unfortunately, MicroPlace stopped its activities on January 14th, 2014. Kiva, created in 2005, is the first comer in the microfinance crowdfunding field or "crowdmicrofinance". It is today the leader of the market.

The coming of crowdfunding demonstrates a new step in the evolution of microfinance, from a classical model to a crowdmicrofinance model, that of the 21st century. From a group-lending model, in offline microfinance, we slide to one of group-investing which will fund an individual borrower in online microfinance. This slide permits MFIs intermediation costs to be brought much lower and thus to charge lower interest rates to borrowers [26]. This new medium of communication, by getting rid of geographical barriers in a more and more global village [27], allows to efficiently complete the action of microfinance to divide by two extreme poverty, as it is targeted in the first Millennium Development Goals developed by the United Nations.

Crowdfunding creates a lot of opportunities insofar it is suitable for different sizes of enterprises and projects. The cost of funding is low compared to traditional ways of fundraising. Launching a campaign is very fast as well as giving explanation about the project to many people at once while covering a large area. Finally posting a project on a website offers an immediate feedback on the viability of the idea. Most of or all the platforms, especially in the microfinance field, use storytelling to market their action. 
They use pictures of future borrowers to depict their story for potential lenders. This promotion of storytelling contributes to a renewed vision even embellished of entrepreneurship financing. Technological innovations make it possible to raise money outside the circle of people that we know. Through the uncountable possibilities given by the Internet, proximity relationships between entrepreneurs and investors are redefined. They allow to augment the possibilities of "positive connexion" between them. All these elements lead to a positive answer to our title question. Crowdfunding is an accelerator of poverty alleviation.

Nevertheless, this sector is not free from threats. A consistent fear is felt by investors to lend money to people they will never meet because of the risk of fraud by disappearance of money through the Internet or of misuse of their money. National regulations try to avoid this risk by disclosure requirements. Platforms, as well as MFIs, must struggle for sustainability and profitability, be they lender-based model as Babyloan or borrower-based as Rang De. Regulatory barriers must be overtook in both cases [26], for instance, that of market limitation to investors within the European Union for the French platforms.

The souvenir of the Internet bubble burst in the late 1990s is still clear in all memories. Internet start-ups knew the same rapid development with a very fast growth of platform numbers and originality of business models. This burst and the consecutive sector concentration witnessed the disappearance of most of these start-ups and the apparition of robust leaders.

\section{Conclusions}

"Banking is necessary; banks are not". This Bill Gates's sentence sounds particularly accurate for crowdmicrofinance. It might be softened insofar as crowdfunding platforms largely collaborate with banks and complete their activity. However, this is the sign of a re-humanization of finance. In a society searching for sense, crowdmicrofinance enables people to give sense to their money by supporting local initiatives and social projects. Thus, crowdfunding contributes to the formation of new communities of "donors" and "counter donors" according to [28] acceptation run by relationships of moral, financial or affective concerns.

This new proximity and connection paradoxically created through the Internet raise new hope for poverty alleviation. Indeed, with good communication around crowdfunding in general and entrepreneurial projects in particular, crowdmicrofinance could fulfil its mission of poverty eradication rapidly.

\section{Acknowledgements}

I would like to thank Fédération Nationale des Banques Populaires and Banque Populaire de Bourgogne Franche-Comté for their support of Banque Populaire Chair in Microfinance of Burgundy School of Business.

\section{References}

[1] Attuel-Mendès, L. (2012) Is Microcredit a Real Innovation? In: Barnett, W. and Jawadi, F., 
Eds., International Symposia in Economic Theory and Econometrics. Recent Developments in Alternative Finance: Empirical Assessments and Economic Implications, Emerald Publishing, Bingley, 235-245. https://doi.org/10.1108/s1571-0386(2012)0000022017

[2] Attuel-Mendès, L. (2014) Crowdfunding Platforms for Microfinance: A New Way to Eradicate Poverty through the Creation of a Global Hub? Cost Management, 28, 38-47.

[3] Woller, G.M., Dunford, C. and Woodworth, W. (1999) Where to Microfinance? Draft Paper, $25 \mathrm{p}$.

[4] Observatoire des inégalités (2015) La pauvreté Baisse dans le Monde mais de Fortes Inégalités Persistent entre Territoires. http://www.inegalites.fr/spip.php?article381

[5] Chang, H.-J. (2010) Poverty, Entrepreneurship, and Development. http://www.wider.unu.edu/publications/newsletter/articles-2010/en_GB/10-2010-Chang/

[6] Schreiner, M. and León, J. (2002) Microfinance for Microenterprise: The State of the Art. Savings and Development, 26, 329-354.

[7] Schreiner, M. and Woller, G. (2003) Microenterprise in the First and Third Worlds. World Development, 31, 1567-1580. https://doi.org/10.1016/S0305-750X(03)00112-8

[8] Yunus, M. (1999) Banker to the Poor. Public Affairs, New York.

[9] Boyé, S., Hajdenberg, J. and Poursa, C. (2009) Le Guide de la Microfinance. Eyrolles, Paris.

[10] Ghatak, M. (2000) Screening by the Company You Keep: Joint Liability Lending and the Peer Selection Effect. Economic Journal, 110, 601-631. https://doi.org/10.1111/1468-0297.00556

[11] Ghatak, M. and Guinnane, T.W. (1999) The Economics of Lending with Joint Liability: Theory and Practice. Journal of Development Economics, 60, 195-228. https://doi.org/10.1016/S0304-3878(99)00041-3

[12] Servet, J.M. (2006) Banquiers aux Pieds nus, La microfinance. Odile Jacob, Paris.

[13] De Lutzel, E. (2009) Les Banques, Médiateurs de la Microfinance Internationale. Revue Banque, 714, 44-46.

[14] Ashta, A. and Assadi, D. (2010) Should Online Micro-Lending Be for Profit or for Philanthropy? DhanaX and Rang De. Journal of Innovation Economics and Management, 2, 123 146. https://doi.org/10.3917/jie.006.0123

[15] Baromètre de la Microfinance/Convergences (2015). http://www.microfinancegateway.org/sites/default/files/publication_files/fr_mfg_barometre 8042015.pdf

[16] ResponsAbility (2015) Microfinance Market Outlook 2015.

[17] Lambert, T. and Schwienbacher, A. (2010) An Empirical Analysis of Crowdfunding.

[18] Schwienbacher, A. and Larralde, B. (2012) Crowdfunding of Small Entrepreneurial Ventures. In: Cumming, D., Ed., The Oxford Handbook of Entrepreneurial Finance, Chapter 13, Oxford University Press, Oxford.

[19] European Crowdfunding Network (2013). http://www.eurocrowd.org/2013/04/about-us/

[20] Massolution (2015) Crowdfunding Iindustry Report. http://reports.crowdsourcing.org/index.php?route=product/product\&product_id=54

[21] Belleflamme, P., Lambert, T. And Schwienbacher, A. (2010) Crowdfunding: An Industrial Organization Perspective. Digital Business Models. Understanding Strategies, Paris, 25-26 June 2010, 1-30.

[22] Kitchens, R. and Torrence, P.D. (2012) The JOBS Act-Crowdfunding and Beyond. Economic Development Journal, 11, 42-47. 
[23] Attuel-Mendès, L. and Collin, V. (2015) Les Différentes Voies d'Association d'une Banque de Proximité aux Plateformes de Crowdfunding. Cahiers du CEREN, 47, 41-65.

[24] Burand, D. (2009) Microfinance Managers Consider Online Funding: Is It Finance, Marketing, or Something Else Entirely? Focus Note 54, CGAP, Washington DC.

[25] Barry, J.J. (2012) Microfinance, the Market and Political Development in the Internet Age. Third World Quarterly: Journal of Emerging Areas, 33, 125-142.

[26] Marakkath, N. and Attuel-Mendès, L. (2015) Can Microfinance Crowdfunding Reduce Financial Exclusion? Regulatory Issues. International Journal of Bank Marketing, 33, 624636. https://doi.org/10.1108/IJBM-06-2014-0080

[27] Mac Luha, M. (1967) War and Peace in the Global Village. Bantam Books, New York.

[28] Mauss, M. (1968) Essai sur le Don. Forme et Raison de l'Échange dans les Sociétés Primitives. $4^{\text {ème }}$ éd., Sociologie et anthropologie, PUF, 482 p.

Submit or recommend next manuscript to OALib Journal and we will provide best service for you:

- Publication frequency: Monthly

- 9 subject areas of science, technology and medicine

- Fair and rigorous peer-review system

- Fast publication process

- Article promotion in various social networking sites (LinkedIn, Facebook, Twitter, etc.)

- Maximum dissemination of your research work

Submit Your Paper Online: Click Here to Submit

Or Contact service@oalib.com 